\title{
Case Histories of Ancient Silver Embrittlement
}

\author{
R. J. H. Wanhill
}

Submitted: 2 November 2010/Published online: 4 January 2011

(C) ASM International 2011

\begin{abstract}
This article discusses six cases of ancient silver embrittlement. The diagnostic techniques and results are surveyed, followed by the most likely explanations of embrittlement. There are two basic types of embrittlement: corrosion-induced, and microstructurally induced, which can act synergistically. Corrosion-induced embrittlement takes several forms, including what appears to be intergranular and transgranular stress corrosion cracking. The main intrinsic factor facilitating corrosion-induced embrittlement is retained cold-work in the silver. Microstructural embrittlement is characterized by intergranular fracture, most probably due to low-temperature segregation of lead to the grain boundaries. Knowledge of the details of embrittlement can be essential for optimizing the restoration and conservation of damaged artifacts.
\end{abstract}

Keywords Ancient silver - Embrittlement - Case histories

\section{Introduction}

Ancient silver artifacts are rare and valuable exhibits in many museums. Some are apparently in excellent condition, but others may have been badly damaged and embrittled during many centuries of burial. Preservation of these artifacts depends, or should depend, on a detailed understanding of the types of damage and embrittlement.

Since 1994, the NLR has investigated four cases of ancient silver embrittlement [1-7], one as a re-assessment

R. J. H. Wanhill ( $\square)$

National Aerospace Laboratory NLR, P.O. Box 153, 8300 AD

Emmeloord, The Netherlands

e-mail: wanhill@nlr.nl
[7], and reviewed two cases investigated by others [8-11]. Experience and insight gained from the investigations enables presenting the most likely explanations of embrittlement for all six cases. This is the main topic of this article.

\section{The Artifacts}

Five of the ancient silver artifacts are illustrated in Figs. 1-5. The Gundestrup Cauldron, Egyptian Vase, and Roman Kantharos (drinking cup) are about 2000 years old. The Byzantine Paten (altar plate) and Romanesque Kaptorga (small container for relics and amulets) date from the 7th and 10th centuries AD, respectively. The sixth artifact is a Sasanian King's Head [11], dating from the 4th century AD. The Kaptorga and Head are the subjects of the reviewed cases mentioned above [8-11].

The artifacts are very different in form and origin. This is advantageous for the consistency of some of the explanations of the types of embrittlement.

\section{Diagnostic Techniques}

Table 1 lists the diagnostic techniques (besides visual observation) used for examining small (usually millimetersize) samples from the artifacts. Limitations were imposed by the available samples and techniques. Fractography could not be done on the metallographic samples from the Cauldron and Paten; chemical analyses other than EDX were not possible for the Vase and Kaptorga; and EBSD was available only for the Cauldron. Also, only a sample from the Kantharos inner cup was available. 


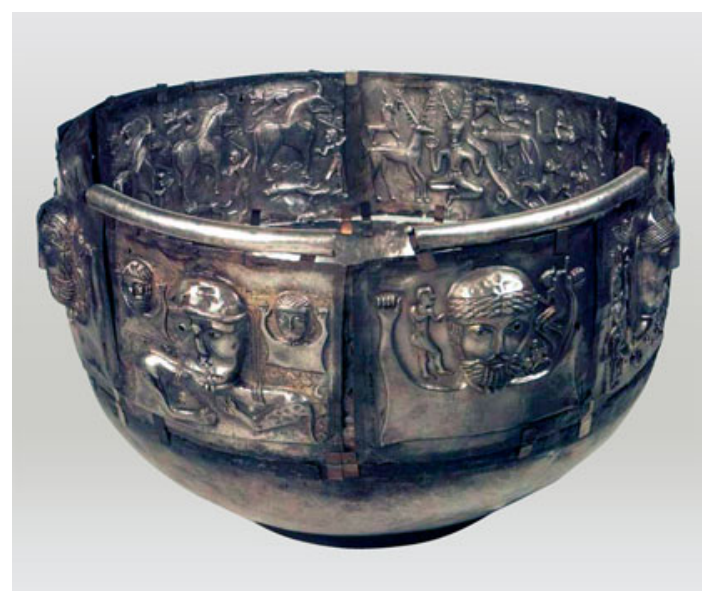

Fig. 1 Gundestrup Cauldron, diameter, $60 \mathrm{~cm}$ : National Museum of Denmark, Copenhagen

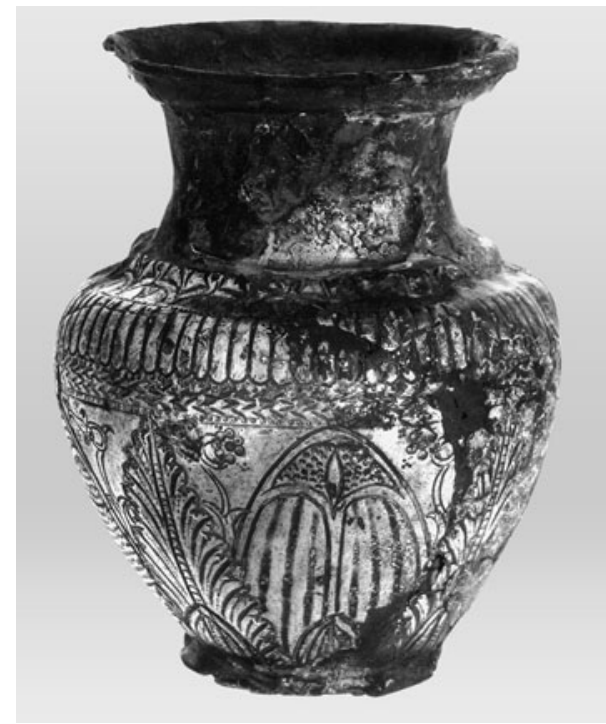

Fig. 2 Egyptian Vase, height, $9.6 \mathrm{~cm}$ : Allard Pierson Museum, Amsterdam

\section{Survey of the Results}

Tables 2 and 3 depict the survey of the results of the investigations. The results are discussed in the two main sections of this article later, where links between the types of embrittlement, artifact microstructure, and composition are indicated. For the Kaptorga, the possible contribution of the burial environment, a grave, is also considered.

\section{Corrosion-Induced Embrittlement}

Intergranular Corrosion and Cracking

Tables 2 and 3 show that corrosion-induced intergranular embrittlement was observed in samples from the

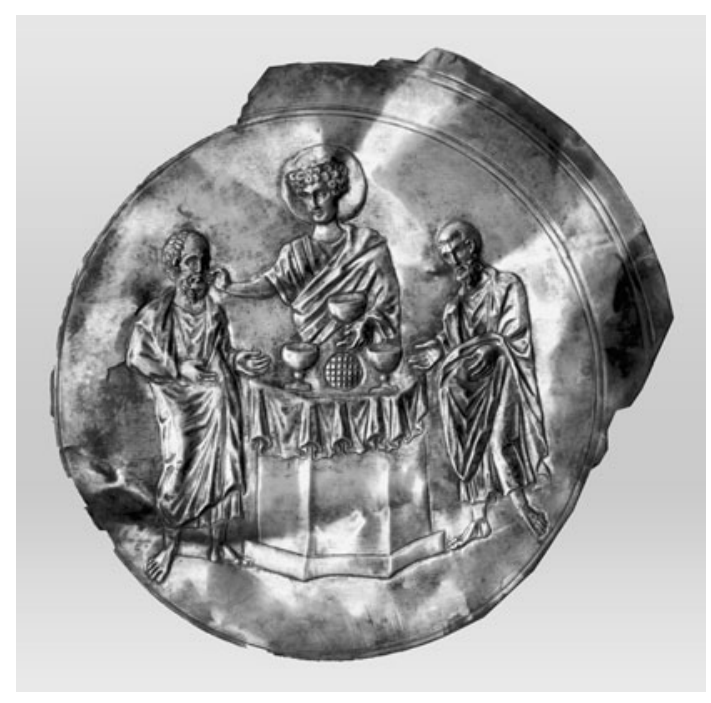

Fig. 3 Byzantine Paten, inner diameter, $20 \mathrm{~cm}$ : The Menil Collection, Houston

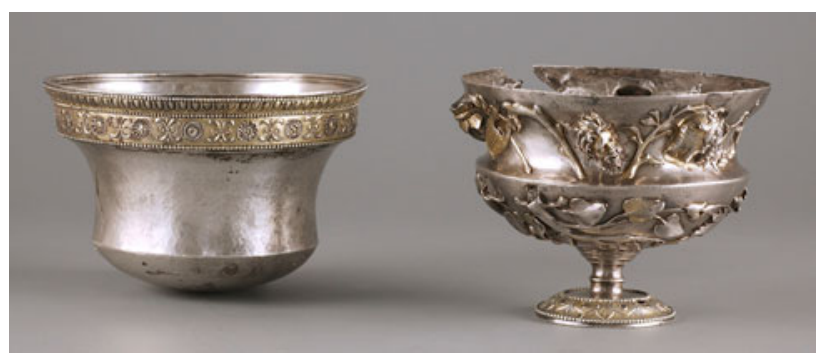

Fig. 4 Roman Kantharos, inner and outer cups, top diameter, $12.7 \mathrm{~cm}$ : Museum Het Valkhof, Nijmegen

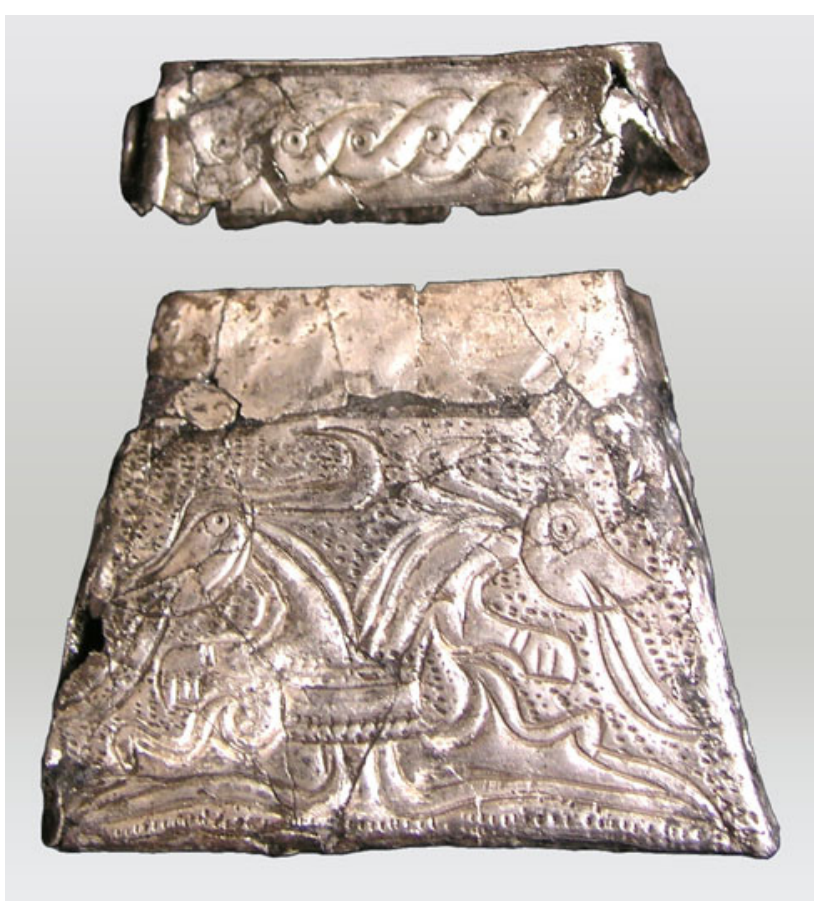

Fig. 5 Romanesque Kaptorga, maximum width, $4.6 \mathrm{~cm}$ : Institute of Archaeology, Prague 
Table 1 Diagnostic techniques used to examine the ancient silver artifacts

\begin{tabular}{|c|c|c|c|c|c|c|}
\hline Techniques & Cauldron & Vase & Paten & Kantharos & Kaptorga & Head \\
\hline $\mathrm{X}$-ray radiography & & $\bullet$ & & $\bullet$ & & \\
\hline Optical metallography & & & & & - & $\bullet$ \\
\hline Vickers microhardness, HV & & $\bullet$ & & & & $\bullet$ \\
\hline SEM metallography & $\bullet$ & $\bullet$ & $\bullet$ & & $\bullet$ & \\
\hline Electron backscatter diffraction (EBSD) & $\bullet$ & & & & & \\
\hline SEM fractography & & $\bullet$ & & $\bullet$ & $\bullet$ & \\
\hline EDX chemical analysis & $\bullet$ & $\bullet$ & $\bullet$ & & - & \\
\hline Chemical analysis $^{\mathrm{a}}$ & - & & - & $\bullet$ & & - \\
\hline
\end{tabular}

${ }^{\text {a }}$ EPMA (Cauldron, Paten); XRF (Kantharos); semi-quantitative spectrography (Head)

Table 2 Survey of the results of the investigations of samples from the ancient silver artifacts

\begin{tabular}{|c|c|c|c|c|c|c|}
\hline Observations & Cauldron & Vase & Paten & Kantharos & Kaptorga & Head \\
\hline \multicolumn{7}{|l|}{ Corrosion embrittlement } \\
\hline Intergranular & 3 samples & & - & & $\bullet$ & $\bullet$ \\
\hline Transgranular & 1 sample & $\bullet$ & & & & \\
\hline Microstructural embrittlement & & $\bullet$ & & $\bullet$ & & \\
\hline Annealed microstructure & 1 sample & & $\bullet$ & $\bullet$ & $\bullet$ & \\
\hline Retained cold-work & 3 samples & $\bullet$ & & & & $\bullet$ \\
\hline Discontinuous precipitation of copper & 1 sample & & $\bullet$ & & & b.d. \\
\hline \multicolumn{7}{|l|}{ Chemical composition $^{\mathrm{a}}$, wt. $\%$} \\
\hline $\mathrm{Cu}$ & $1.76-4.64$ & 0.9 & 5.33 & $0.45-0.63$ & $3.3-3.5$ & $\sim 5$ \\
\hline $\mathrm{Au}$ & $0.29-0.36$ & 0.8 & 0.58 & $0.58-0.63$ & $2.3-2.5$ & $0.1-1$ \\
\hline $\mathrm{Pb}$ & $0.39-0.64$ & 0.7 & 0.86 & $0.16-0.25$ & n.d. & $0.05-0.5$ \\
\hline $\mathrm{Bi}$ & $0.07-0.13$ & n.d. & 0.06 & n.d. & n.d. & $0.01-0.1$ \\
\hline Surface corrosion product mainly $\mathrm{AgCl}$ & & - & & & • & - \\
\hline
\end{tabular}

${ }^{\mathrm{a}}$ Main elements, balance Ag; n.d. = not detectable; b.d. = barely detectable

Table 3 Gundestrup Cauldron samples

\begin{tabular}{|c|c|c|c|c|}
\hline Observations & 361 & 363 & 365 & 366 \\
\hline \multicolumn{5}{|l|}{ Corrosion embrittlement } \\
\hline Intergranular & - & - & - & \\
\hline Transgranular & & & - & \\
\hline Annealed microstructure & & & & - \\
\hline Retained cold-work ${ }^{\mathrm{a}}$ & - & - & - & \\
\hline Discontinuous precipitation of copper & & & & $\bullet$ \\
\hline Copper content, wt.\% & 4.64 & 1.76 & 2.17 & 3.44 \\
\hline
\end{tabular}

${ }^{a}$ Increasing retained cold-work in the order $361<363<365$

Cauldron, Paten, Kaptorga and Head [4-6, 8-11]. This type of embrittlement has been attributed to segregation of copper to grain boundaries, either during cooling from final annealing during fabrication, or during long-term burial at ambient temperatures [9, 12-15]. In particular, the eminent metallurgist C. S. Smith was of the opinion that the so-called discontinuous precipitation of copper seems to be very detrimental [12]. This precipitation can cause the grain boundaries to appear irregular and meandering, particularly in ancient silver.

The unembrittled sample 366 from the Cauldron and the embrittled Paten and Head samples showed evidence of discontinuous precipitation, see Figs. 6-8. However, the embrittled samples from the Cauldron and Kaptorga did not. Hence, this type of precipitation is not needed for corrosion-induced intergranular embrittlement, and in the case of the Cauldron, it was innocuous.

For the Cauldron, the EBSD examination demonstrated a strong link between the amount of retained cold-work, degree of embrittlement and the presence or absence of discontinuous precipitation [4-6]. Figures 6 and 9 show examples from the two extremes, samples 365 and 366 . The annealed sample 366, Fig. 6, was undamaged even though precipitation was present at many grain boundaries. However, the heavily cold-worked sample 365, Fig. 9, showed severe intergranular and transgranular corrosion, with no evidence of precipitation. The intermediately cold-worked samples 361 and 363 also showed intergranular corrosion, though less severe, and again without 


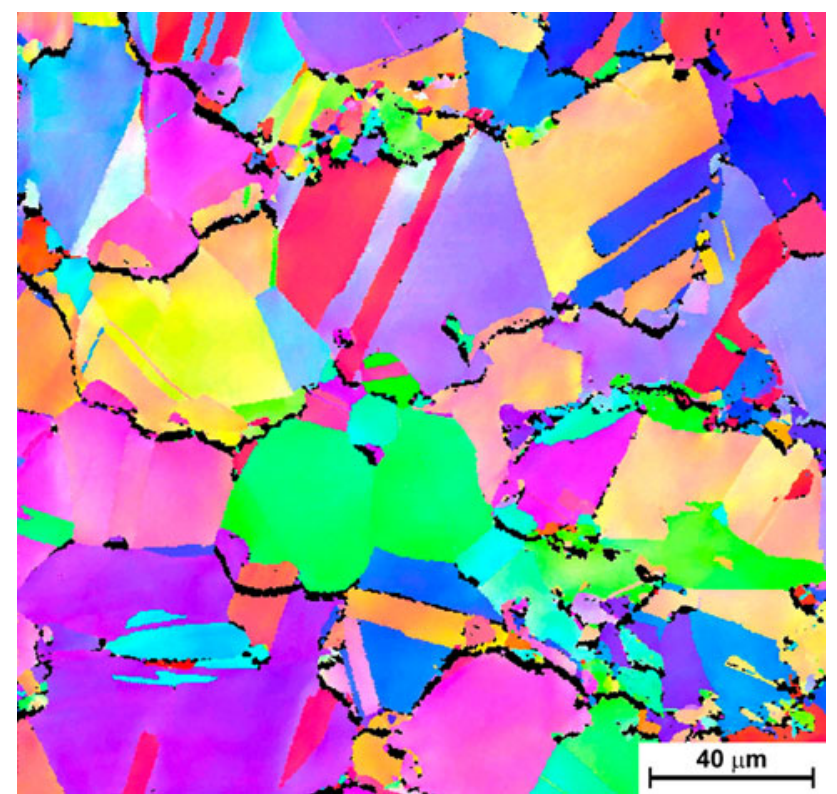

Fig. 6 EBSD inverse pole figure color-coded map of the sample 366 from the Gundestrup Cauldron, showing fully annealed grains, annealing twins, and extensive discontinuous precipitation of copper (delineated by the black dots) at the grain boundaries

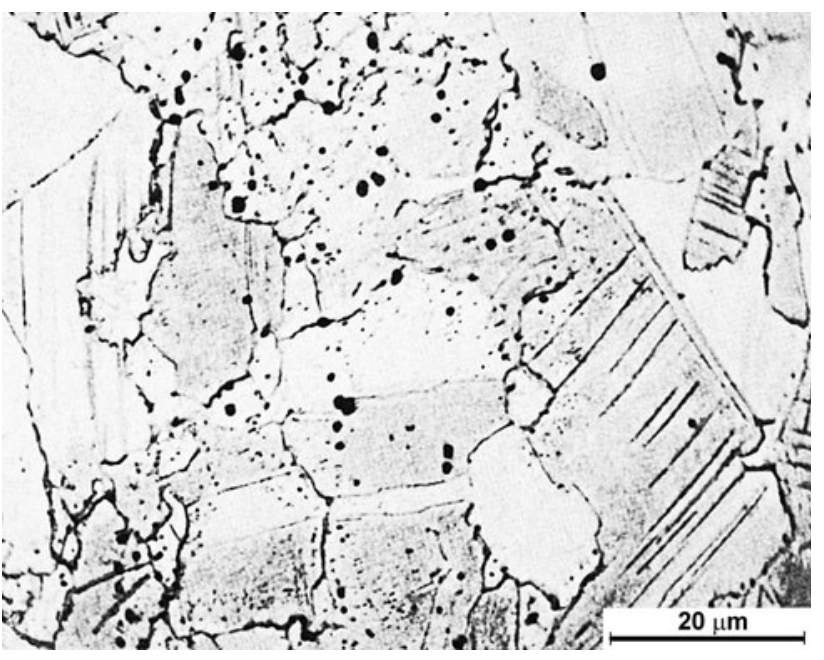

Fig. 8 Optical metallograph of a sample from the Sasanian King's Head [11], showing slightly distorted annealing twin boundaries, deformation twins, and barely detectable discontinuous precipitation of copper at grain boundaries. The black particles are probably copper oxide originating from the time when the metal was cast [11]
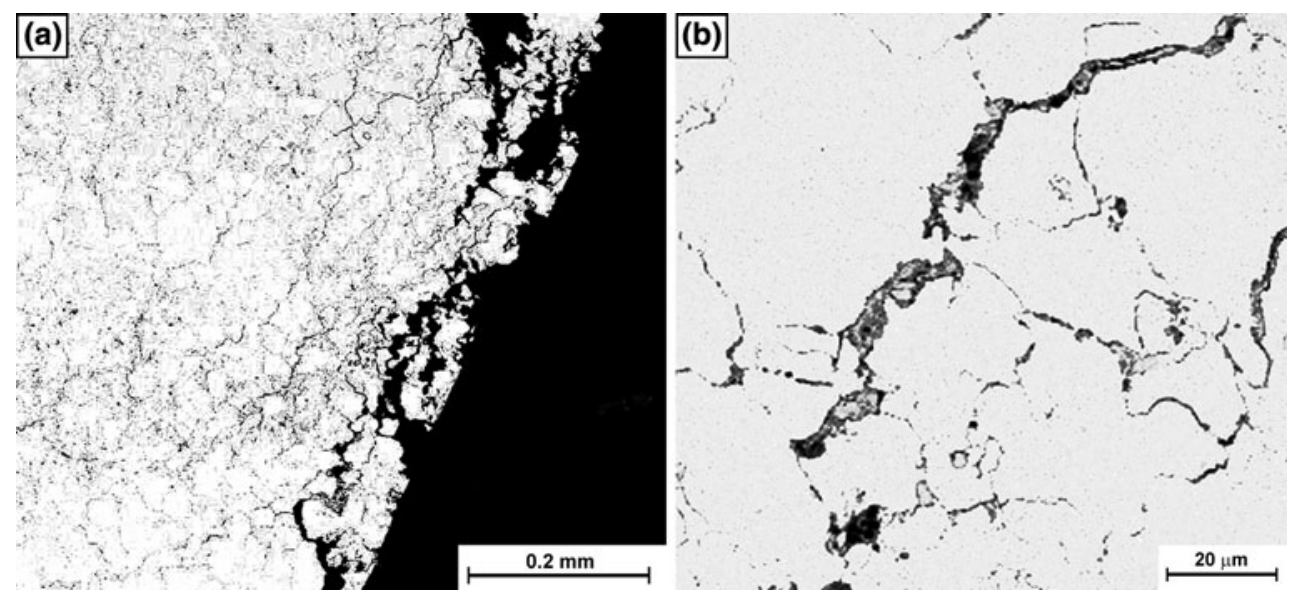

Fig. 7 SEM metallographs of the Byzantine Paten sample, showing (a) intergranular corrosion and cracking and (b) discontinuous precipitation of copper at the grain boundaries [4, 5]: courtesy of Ineke Joosten, Netherlands Institute for Cultural Heritage, Amsterdam

precipitation $[4,5]$. It appears that cold-work suppressed the precipitation, since the annealed sample 366 contained less copper (3.44 wt.\%) than sample 361 (4.64 wt.\%), see Table 3. In this respect, it is noteworthy that precipitation in the cold-work-containing Head (84 HV vs. $43 \mathrm{HV}$ fully annealed) was barely detectable, Fig. 8, even though the copper content was about 5 wt.\% [11].

Although the Cauldron results show retained cold-work is important, it is not always needed for corrosion-induced intergranular embrittlement. The Kaptorga has a fully annealed microstructure (without discontinuous precipitation, as mentioned above) but has been severely embrittled and highly fragmented [8-10]. Figure 10 shows an SEM metallograph and fractograph of samples showing (a) corrosion pitting at grain boundaries, linking to form cracks, and (b) corrosion-induced "clean" intergranular fracture being slowly destroyed by general corrosion. By analogy with clean intergranular stress corrosion cracking (SCC) followed by general corrosion in an aluminiumlithium alloy [16], the Kaptorga intergranular fracture has been suggested to be SCC also [6].

Since the Kaptorga silver was fully annealed [9], SCC would have had to result from external crushing forces combined with a particularly adverse environment. Both 
are distinct possibilities resulting from the grave burial: besides the weight of the soil, especially on hollow artifacts like the Kaptorga, the groundwater in graves can be very saline owing to human decomposition [17]. Support for these possibilities comes from another grave burial artifact, the Khan Cup, which was highly fragmented owing to "crystalline" fracture [18].

Transgranular Corrosion and Cracking

Tables 2 and 3 show that corrosion-induced transgranular embrittlement was observed in samples from the Cauldron (365) and Vase. The Vase has so far proven to be unique in undergoing synergistic corrosion-induced (transgranular)

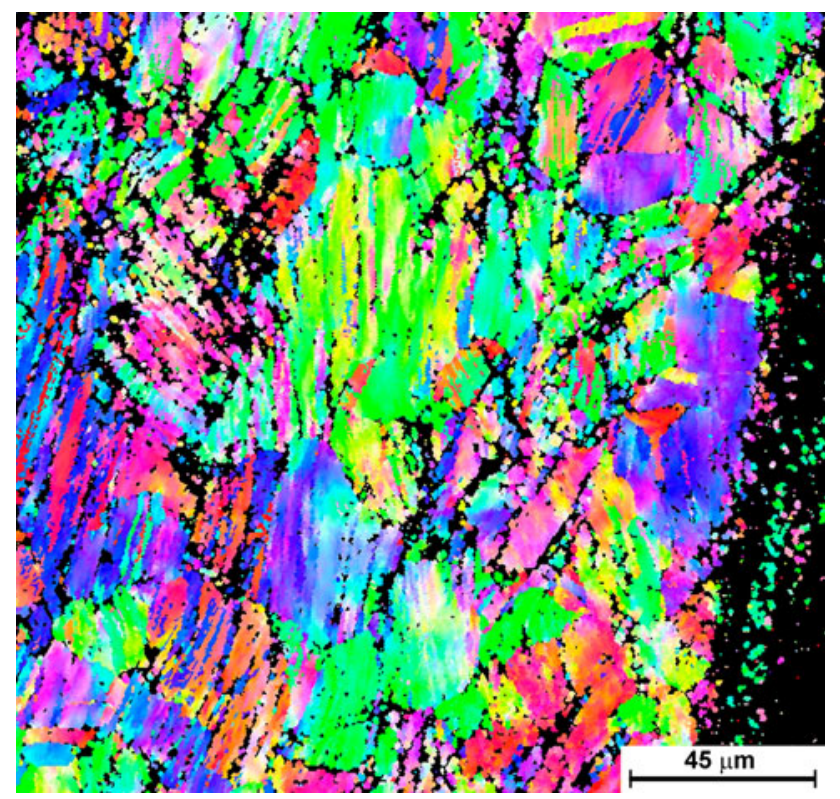

Fig. 9 EBSD inverse pole figure color-coded map of sample 365 from the Gundestrup Cauldron, showing retained cold-work and extensive corrosion-induced intergranular and transgranular fracture (the internal black-dotted areas) and microstructural (intergranular) embrittlement [1-5]. This synergy has been very damaging, but it has enabled the transgranular corrosion and cracking to be well characterized. This is because microstructural embrittlement caused intergranular break-up of the samples and revealed the internally-developing processes of corrosion-induced embrittlement from initiation to complete fracture.

The Vase underwent corrosion and cracking along slip lines and deformation twin boundaries owing to retained cold-work; and also corrosion along segregation bands, which were the much-modified remains of high-temperature solute element segregation (coring) during solidification. Examples are shown in Figs. 11 and 12, whereby the fractograph shows crystallographic cracking mainly along slip planes, followed by general corrosion destroying the fracture surfaces. As in the case of corrosion-induced intergranular embrittlement of the Kaptorga, Fig. 12 suggests a process of SCC, in this case transgranular.

More evidence for transgranular SCC was obtained from intergranular break-up of the samples. Figure 13 illustrates

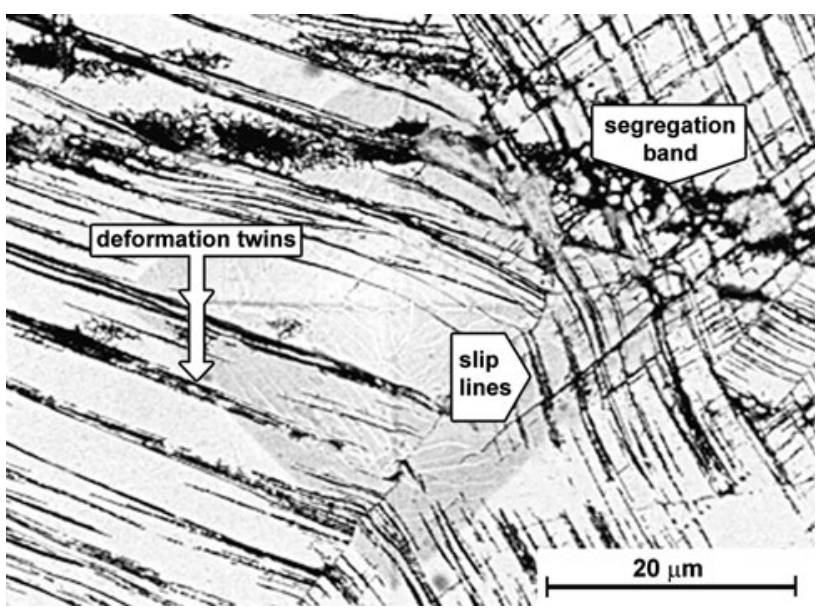

Fig. 11 SEM metallograph of an Egyptian Vase sample showing corrosion along slip lines, deformation twins, and segregation bands. The diamond-shaped "shadow" is from a microhardness indent
Fig. 10 SEM metallograph and fractograph of samples from a Romanesque Kaptorga, showing (a) corrosion pitting at grain boundaries, linking to form cracks, and (b) corrosioninduced "clean" intergranular fracture being slowly destroyed by general corrosion: courtesy of Jiří Děd and Jarka

Vaníčková, Institute of Chemical Technology, Prague
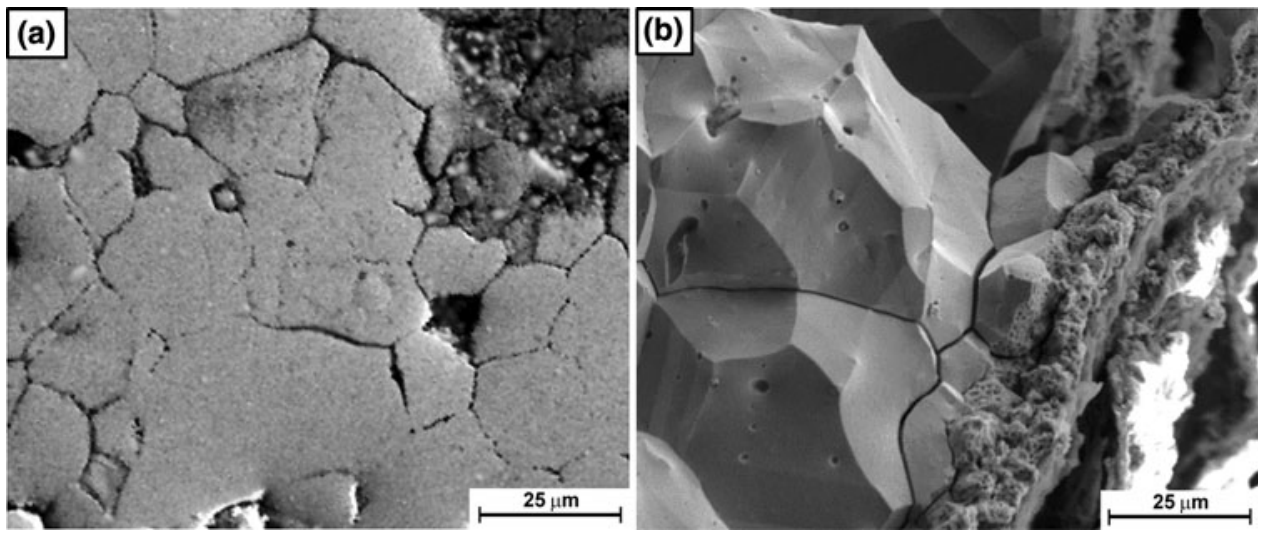
(a) the beginning of slip plane corrosion (pitting, most probably at emergent dislocations), (b) cracking, and (c) the resulting crystallographic fracture into blocks. The $90^{\circ}$ "dog-leg" crack in Fig. 13b is significant, as are the highangle narrow sides of the blocks in Fig. 13c. Given that the slip plane cracks are on $\{111\}$ planes, the "dog-leg" crack cannot be on a $\{111\}$ plane, but must be on either a $\{110\}$ or $\{112\}$ plane. The high-angle block sides are also likely to be on one of these planes. As explained in Ref. [6], these observations favor the strain-enhanced dissolution model of SCC proposed by Lichter et al. [19].

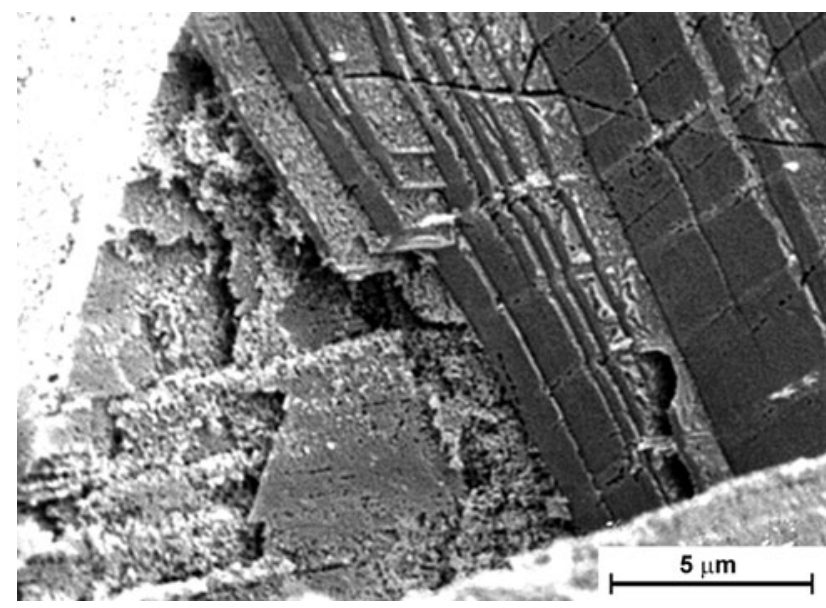

Fig. 12 SEM fractograph of an Egyptian Vase sample showing crystallographic corrosion mainly along slip planes, followed by general corrosion partly destroying the fracture surfaces at the lefthand side of the fractograph
Rationale Linking Intergranular and Transgranular Cracking

The case history evidence may be interpreted to provide an overall rationale for corrosion-induced intergranular and transgranular cracking. Intergranular pitting and cracking is probably SCC caused by local strains (and compositional variations, particularly copper) at and near grain boundaries. The local strains derive from external forces (Kaptorga) and/or retained cold-work (Cauldron, Paten, and Head).

More retained cold-work (Cauldron, sample 365, Vase) increases the tendency for transgranular SCC, which is caused mainly by local strains because of dislocation pileups on slip planes. However, there is some contribution from local strains on "dog-leg" crystallographic planes and deformation twin boundaries.

\section{Microstructural Embrittlement}

Table 2 shows that microstructural embrittlement was observed in samples from the Vase and Kantharos inner cup. This type of embrittlement is fortunately less common than corrosion-induced embrittlement, since it occurs throughout the artifacts, leaving them particularly susceptible to fragmentation. (However, see the comments in the next section of this article concerning the brittleness of the Vase, Kantharos inner cup and Kaptorga.)

Microstructural embrittlement is characterized by zeroductility intergranular fracture, with sharply defined cracks
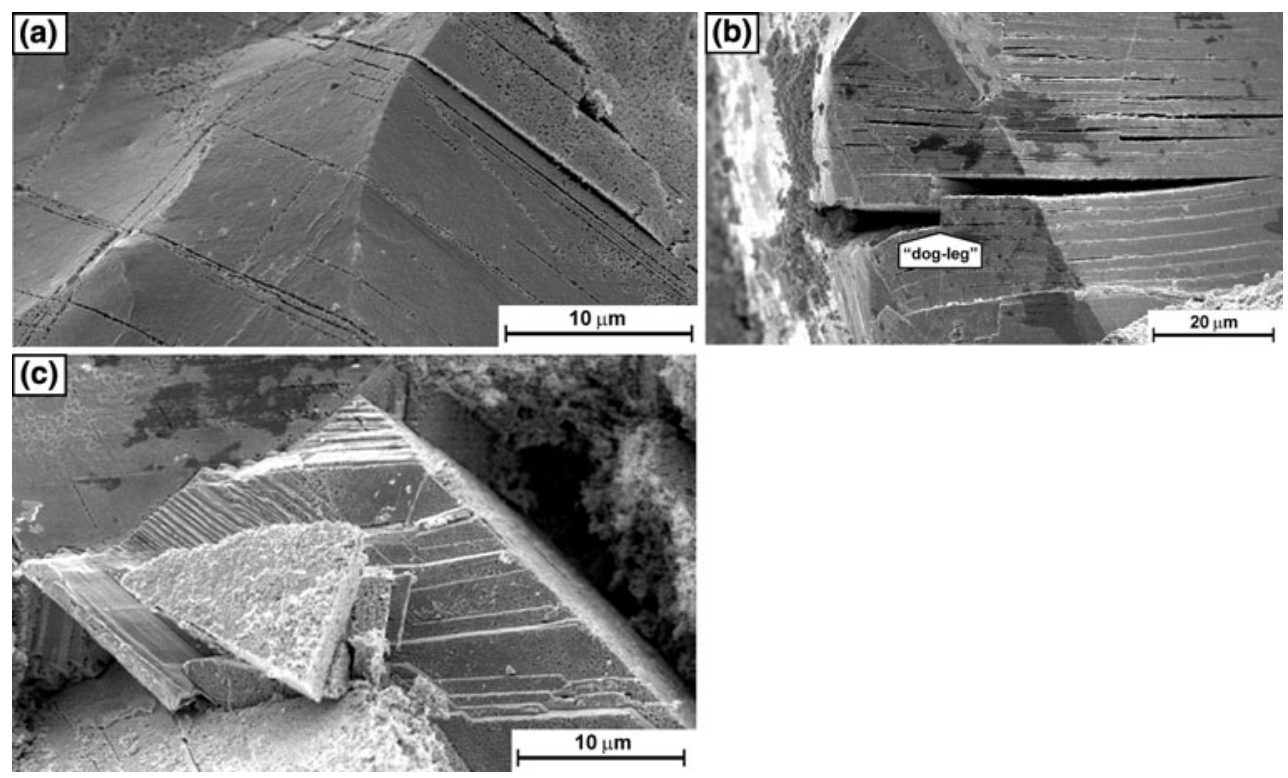

Fig. 13 SEM fractographs of an Egyptian Vase sample showing (a) slip line corrosion, (b) slip plane dissolution and cracking, and (c) crystallographic fracture topography 


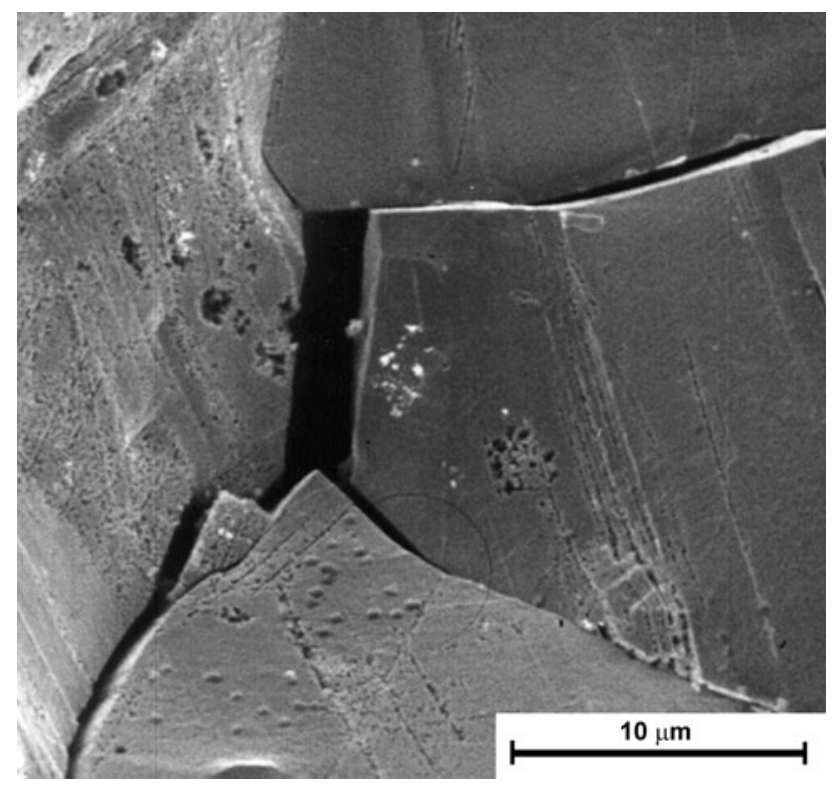

Fig. 14 SEM fractograph of an Egyptian Vase sample showing brittle intergranular fracture with bodily displaced grains owing to microstructural embrittlement. Some slip line corrosion is also present (part of the synergistic embrittlement)

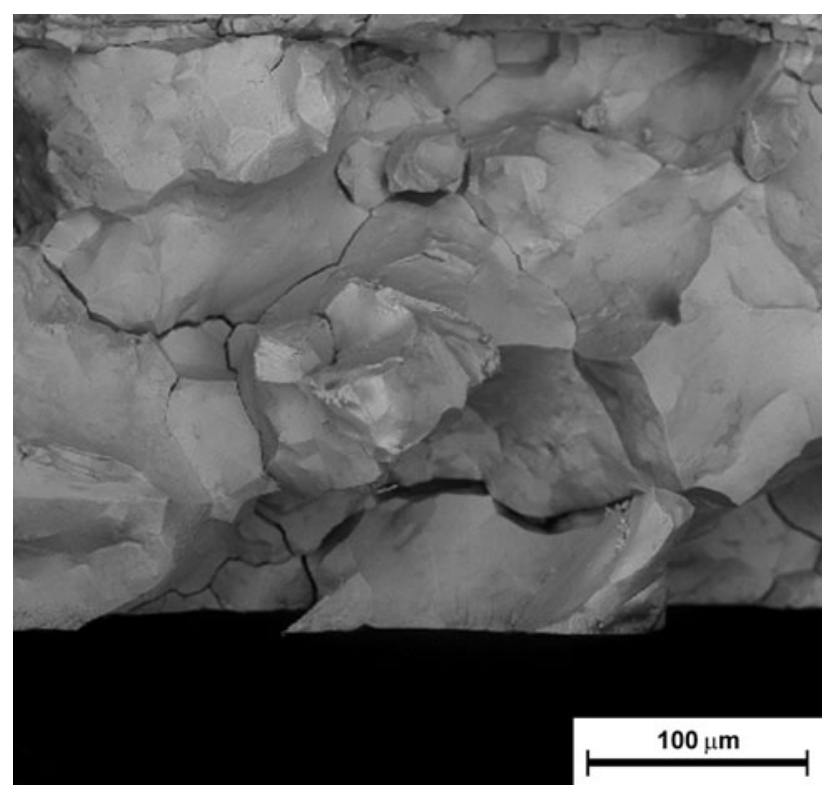

Fig. 15 SEM fractograph (backscattered electron mode) of a Kantharos inner cup sample showing brittle intergranular fracture with bodily displaced grains owing to microstructural embrittlement: courtesy of Ineke Joosten, Netherlands Institute for Cultural Heritage, Amsterdam

and grain boundary facets, and bodily displaced grains [1-6]. Examples are given in Figs. 14 and 15. In particular, the bodily displaced grains demonstrate the severity of this type of embrittlement.

Embrittlement is most probably caused by low-temperature ageing, whereby an impurity element, or elements, segregates to grain boundaries throughout the artifact. The available evidence, including the Vase and Kantharos compositions listed in Table 2, indicates lead to be the most likely perpetrator [20, 21], though this has yet to be verified directly, e.g., by Auger spectroscopy. Other impurity elements might be involved, notably bismuth $[11,21]$, though apparently not for the Vase and Kantharos, see Table 2.

\section{Remedial Measures: Comments from the Case Histories}

Restoration and conservation of embrittled silver has been discussed in many publications, e.g. Refs. $[1,2,4,6-8,11$, $14,18,21-23]$. The modern view is to consider both technical and ethical aspects. Preference is therefore given to reversible remedial measures that respect an artifact's integrity, meaning veracity rather than wholeness. However, the second meaning, wholeness, can dictate the remedial measures: non-reversible consolidation is essential for preserving severely embrittled and fragmented artifacts [8, 10, 18, 22, 23].

Detailed case histories can be important in resolving the issue of reversible versus non-reversible restoration. Looking to the six case histories discussed in this article, the Cauldron, Paten, and Head are in generally good condition. Further conservation measures, if any, would likely be limited to periodic cleaning and possible application of removable protective coatings. Even so, the choice of cleaning methods and coatings requires careful consideration $[4,6,11,22,24]$.

In contrast, the Vase, Kantharos inner cup and Kaptorga have been severely embrittled. From a fundamental point of view, one would expect the Kaptorga to be less fragile than the Vase and Kantharos inner cup. Any non-cracked areas of the Kaptorga should have retained the high ductility of annealed silver now that it is removed from the burial environment, but the Vase and Kantharos inner cups are now intrinsically brittle. In practice, however, the intergranular cracking in the Kaptorga has been so extensive that the fragments continued to break up even during careful handling before restoration [8]. Hence, all three artifacts were very fragile before restoration, and they have been non-reversibly restored.

The Vase restoration is old (and crude by modern standards), involving extensive use of an organic filler material. The Kantharos (both cups) has been restored by impregnation with an epoxy resin [7]. However, the tight cracks shown in Fig. 15 were free of resin, which suggests that the restoration has been only partly successful. The Kaptorga has been very carefully restored using an external and removable backing of silk and acrylic lacquer, 
followed by an internal backing of fine glass cloth and epoxy resin [8]. The external backing was then removed with acetone. This is a similar technique to that used for the Khan Cup [18].

\section{Concluding Remarks}

Ancient silver artifacts are rare and valuable museum exhibits. Consequently, it is difficult to obtain samples from the embrittled artifacts for detailed investigations. However, the case histories discussed in this article demonstrate that modern diagnostic techniques applied to small samples can tell much about the types of embrittlement and the conditions of the sampled artifacts. This knowledge can be essential for optimizing the preservation of these and other damaged artifacts.

Acknowledgments The author is indebted to several colleagues for providing information and assistance with obtaining and analyzing samples from the artifacts discussed in this article: Ron Leenheer, Allard Pierson Museum, Amsterdam; Peter Northover, Oxford University, Oxford; Joanna Cook, The Menil Collection, Houston; Ronny Meijers, Museum Het Valkhof, Nijmegen; Jiří Děd and Jarka Vaníčková, Institute of Chemical Technology, Prague; Ineke Joosten, Netherlands Institute for Cultural Heritage, Amsterdam; and JeanPaul Steijaert and Tim Hattenberg, NLR.

\section{References}

1. Wanhill, R.J.H., Steijaert, J.P.H.M., Leenheer, R., Koens, J.F.W.: Damage assessment and preservation of an Egyptian silver vase (300-200 BC). Archaeometry 40, 123-137 (1998)

2. Wanhill, R.J.H.: Embrittlement in archaeological silver: diagnostic and remedial techniques. JOM-J. Min. Met. Mater. Soc. 55(10), 16-19 (2003)

3. Wanhill, R.J.H.: Brittle archaeological silver: a fracture mechanisms and mechanics assessment. Archaeometry 45, 625-636 (2003)

4. Wanhill, R.J.H.: Embrittlement of ancient silver. J. Fail. Anal. Preven. 5(1), 41-54 (2005)

5. Wanhill, R.J.H.: Embrittlement of archaeological silver and iron. Struct. Integr. Life 9(3), 143-156 (2009)

6. Wanhill, R.J.H., Northover, J.P.: Corrosion-induced embrittlement of ancient silver. Struct. Integr. Life 10(1), 61-69 (2010)

7. Gerhartl-Witteveen, A.M.: De Kantharos van Stevensweert, een zilveren Romeinse beker (The Kantharos from Stevensweert, a silver Roman cup), Museum Het Valkhof, Nijmegen (2006) (in Dutch)

8. Děd, J., Šilhová, A.: Korozní poškození stř́brných předmětů z archeologických nálezů (Corrosion damage of silver objects from archaeological findings). In: Sborník Konference Konzervátorů a Restaurátorů Plzeň, Technické Muzeum v Brně (Proceedings of Conservators and Restorers 2005 Conference Brno), pp. 44-48 (2005) (in Czech)
9. Vaníčková, J., Děd, J., Bartuška, P., Lejček, P.: Intergranular failure of Roman silver artefacts. Mater. Sci. Forum 567-568, 213-216 (2007)

10. Profantová, N., Šilhová, A.: K problematice kaptorg v Čechách. Na základě detailního studia hrobu 22 z Klecan II (The problems of kaptorgas in the Czech Republic. On the basis of detailed study of grave 22 from Klecany II), Památky Archeol, CI, pp. 283-310 (2010) (in Czech)

11. Lefferts, K.C.: Technical notes. MMA Bull. 25(3), 147-151 (1966)

12. Smith, C.S.: The interpretation of microstructures of metallic artifacts. In: Young, W.J. (ed.) Application of Science in Examination of Works of Art, pp. 20-52. Boston Museum of Fine Arts, Boston (1965)

13. Werner, A.E.: Two problems in the conservation of antiquities: corroded lead and brittle silver. In: Young, W.J. (ed.) Application of Science in Examination of Works of Art, pp. 96-104. Boston Museum of Fine Arts, Boston (1965)

14. Ravich, I.G.: Annealing of brittle archaeological silver: microstructural and technological study. In: 10th Triennial Meeting of the International Council of Museums Committee for Conservation, Preprints of the Seminar: August 22/27, 1993, II, Washington, DC, pp. 792-795 (1993)

15. Vaníčková, J., Děd, J., Bartuška, P., Drahokoupil, J., Čerňanský, M., Lejček, P.: Analysis of grain boundaries in an embrittled ancient silver necklace, Surf. Interf. Anal. 40, 454-457 (2008)

16. Schra, L., Wanhill, R.J.H.: Further evaluation of Automated Stress Corrosion Ring (ASCOR) testing of aluminum alloys. J. Test. Eval. 27(3), 196-202 (1999)

17. www.pioneerburials.com: Impact of Human Decomposition on Groundwater-Literature Review. Pioneer Natural Burial Corporation, Davis, CA (2009)

18. Stawinoga, G.: Die Tasse des Khans: Die Restaurierung einer mittelalterlichen Silbertasse (The Khan Cup: the restoration of a mediaeval silver cup). Arbeitsblätter für Restauratoren 30(2), 137-142 (1997) (in German)

19. Lichter, B.D., Lu, H., Flanagan, W.F.: Strain-enhanced dissolution: a model for transgranular stress-corrosion cracking. In: Matsumura, M., Nagano, H., Nakasa, K., Isomoto, Y (eds.) Proceedings of the 2nd International Conference on Environment Sensitive Cracking and Corrosion Damage, pp 271-278. Nikishi Printing Ltd., Hiroshima (2001)

20. Thompson, F.C., Chatterjee, A.K.: The age-embrittlement of silver coins. Stud. Conserv. 1, 115-126 (1954)

21. Wanhill, R.J.H.: Archaeological Silver Embrittlement: A Metallurgical Inquiry, NLR-TP-2002-224. National Aerospace Laboratory NLR, Amsterdam (2002)

22. Organ, R.M.: The current status of the treatment of corroded metal artifacts. In: Corrosion and Metal Artifacts, NBS Special Publication 479, pp. 107-142. National Bureau of Standards/U.S. Department of Commerce, Washington, DC (1977)

23. Gasteiger, S., Eggert, G.: How to compare reduction methods for corroded silver finds. In: McLeod, I.D., Theile, J.M., Degrigny, C. (eds.) Metal 2001, Proceedings of the International Conference on Metals Conservation, Santiago, 2001, pp. 320-324. Western Australian Museum, Fremantle (2004)

24. Van Reekum, J., Moll, E.: Coating silverware: from daily use to museum object. In: Ankersmit, H.A., Mosk, J.A. (eds.) Zeven Ijzersterke Verhalen over Metalen (Seven Steel-Strong Tales about Metals), pp. 74-79. Netherlands Institute for Cultural Heritage, Amsterdam (2000) (in Dutch) 